\title{
Case Study Analysis: The Utilization of Health Services by Citizens at Area of Tangerang Selatan, Indonesia
}

\author{
Putri Permatasari* (D), Cahya Arbitera, Dwi Mutia Wenny \\ Department of Public Health, Faculty of Health Sciences, University of Pembangunan Nasional Veteran Jakarta, Raya limo \\ Street, Depok, Indonesia
}

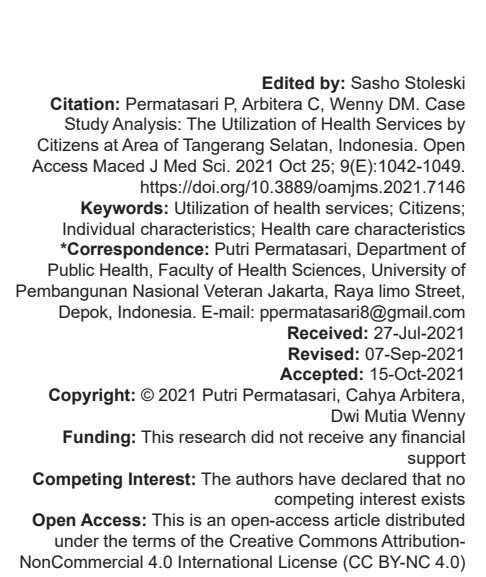

\section{Preliminary}

The government puts great effort into the development and development of health facilities in Indonesia. This is to realize the great aspirations of the Indonesian people to become a developed country by promoting health for healthy generations to come [1]. All stakeholders in health have hopesand goals to beachieved, namely quality health services; therefore, strengthening health services is needed. One of the improvements in the quality of health services is by increasing access to health services to facilitate the community in utilizing health services. Increasing access can be proven by the development and construction of health service facilities. The government has built 10,134 health services in Puskesmas in 2015-2019 which has increased by 70 Puskesmas per year. There are also 9205 clinics and 2877 hospitals. The improvement of health services shows the government's efforts in developing and developing health services for the advancement of the Indonesian nation in the health sector [2].

The government is making great efforts in increasing the development and development of health services. However, the Indonesian people have not made much use of health services when they are sick. According to the Social Survey of the National Ekonimi in 2019 showed that people who have sick by $32.36 \%$.

However, the number of people having health complaints and ouLandfill Areatient treatment was $50.48 \%$.

Utilization of health services is very important to support public health problems. Problems that arise in society are divided into several factors. According to Blum, the factors that influence public health have four main factors, namely, genetic factors, health-care factors, behavioral factors, and environmental factors. These four factors are interrelated, the utilization of health services by the state of the environment also have relationships with each other to improve the degree of public health [3].

One example of an unhealthy environment is a landfill. Area is a useful location for collecting waste and is the end of waste treatment. There are many negative impacts arising from the landfill area, namely damage to infrastructure due to passing garbage trucks, environmental pollution such as community well water due to leaks of residual waste water, and meta gas caused by decomposing organic waste. Other impacts are in the 
form of dust, foul odor, corm or noise pollution [4]. There are many negative impacts from landfill area. However, there are still many people who depend on landfill for their lives, one of which is citizens. Citizens can be interpreted as informal small businesses or independent laskar. Citizens are a group that collects waste to get used goods which people have no price for, but for them it is a source of income for food [4]. The work environment for citizens is an environment that has a high hazard which can affect the health of the citizens. Physical environmental factors with hot temperatures can dehydrate citizens. It can also happen that the pile of garbage carried by citizens is too heavy, which causes a feeling of soreness. Biological factors in the form of bacteria are also present in the landfill due to the humid conditions of the landfill. All of these things can endanger the health of the citizens [5].

Based on the annual report that the village wells stone has an area of \pm 568955 ha. Part of the area becomes an area which has an area of 20 ha for the area until DKI Jakarta and 21 ha for the Tangerang Selatan City landfill area. The quality of the physical environment in Kelurahan Sumurbatu is partly polluted by final development sites such as wells, air, and agricultural land, all of these things happen because waste management has not been as expected. The problem in Setu Village is the existence of the Setu landfill area. The existence of this area makes many residents rely on the area as a source of income, one of which is the citizens who citizens at the Setu landfill area. The number of citizens in the Tangerang Selatan, Indonesia area is 206 families. According to data from the Tangerang Selatan, Indonesia Health Center for 2 years there were 9777 cases of ARI, 1857 cases of dermatitis, 1634 casesofprimary(essential)hypertension, 1500 cases of gastritis and duodenitis, 1262 cases of myalgia, 1246 cases of diarrhea and gastroenteriricism, 1116 cases of acute nasopharyngitus, 755 cases of chepalgia, and 681 cases of acute pharyngitis.

This shows that it is very important for the community to get health services so that they are appropriate in overcoming disease. The use of health services is very important for citizens to improve their health. Furthermore, in this study can provide views of health services in Tangerang Selatan, Indonesia so that they can provide services to citizens according to their needs. Therefore, based on the background of the existing problems, the researcher intends to conduct research on factors related to the use of health services by citizens at the area of Tangerang Selatan, Indonesia, Setu District, Tangerang Selatan City in 2020.

\section{Method}

This research was conducted to determine the relationship between the use of health services by citizens in the landfill of Tangerang Selatan, Indonesia. In this study, there were 206 households using the random sampling technique. The analysis used is Chi-square analysis and Multiple Logistic Regression. This study has limitations related to the research target, namely a citizen who has used health services. The data used are primary data by means of interviews through questionnaires. This research was conducted using quantitative methods using cross-sectional research design.

\section{Results}

\section{Univariate results}

\section{Description of health service utilization}

Based on Table 1 above, it shows that in a period of 1 year from 150 citizens families, it was found that more citizens did not take advantage of health services, namely, as many as 83 citizens (55.3\%). Meanwhile, only 67 citizens families (44.7\%) used health services.

Table 1: Distribution of frequency of health service utilization

\begin{tabular}{lll}
\hline Utilization of health services & Amount & Percentage \\
\hline Yes & 67 & 44.7 \\
No & 83 & 55.3 \\
Total & 150 & 100 \\
\hline Source: Primary data, 2021 & &
\end{tabular}

\section{Characteristics of citizens}

Based on the frequency distribution Table 2 above, it shows that the most knowledge variables are in the less category of 106 families (70.7\%). In the variable of health insurance ownership, most of the citizens stated that they did not have health insurance for 118 families $(78.7 \%)$. Then, the variable number of families was mostly in the small family category of 103 families $(68.7 \%)$. In the transportation variable, the

Table 2: Frequency distribution of citizens characteristics

\begin{tabular}{lll}
\hline Characteristic & Amount & Percentage \\
\hline Knowledge & 44 & 29.3 \\
$\quad$ Good & 106 & 70.7 \\
$\quad$ Less & 32 & 21.3 \\
Health Insurance & 118 & 78.7 \\
$\quad$ Have & & \\
$\quad$ Don't Have & 103 & 68.7 \\
Number of Families & 47 & 31.3 \\
$\quad$ Small & 123 & 82 \\
$\quad$ Big & 27 & 18 \\
Transportation & & \\
$\quad$ Easy & 70 & 46.7 \\
$\quad$ Difficult & 80 & 53.3 \\
Perception of pain & & 34,7 \\
$\quad$ Good & 52 & 65.3 \\
$\quad$ Less & 98 & 40 \\
Family Support & & 60 \\
$\quad$ Good & 60 & 100 \\
$\quad$ Less & 90 & \\
Reference Group Support & 150 & \\
$\quad$ Good & & \\
Less & &
\end{tabular}


most in the easy category was 123 families (82\%). In the perception variable of pain, the most citizens were included in the less category of 80 families (53.3\%). Then, the variables of family support and reference group support were mostly in the less category at $98(65.3 \%)$ and $90(60 \%)$.

\section{Description of health service characteristics}

Based on the frequency distribution above, it shows that the distance variable mostly falls into the close category of 112 households $(74.7 \%)$. Then, in the health information variable, the most citizens stated that there was no health information for 128 households (85.3). In the attitude variable of health workers, the most citizens stated that the attitude of health workers in serving was less than 90 families (60\%) (Table 3).

Table 3: DFrequency Distribution of Health Services Characteristics

\begin{tabular}{lll}
\hline Characteristics & Amount & Percentage \\
\hline Distance & 112 & 74.7 \\
$\quad$ Close & 38 & 25.3 \\
$\quad$ Far & & \\
Health information & 22 & 14.7 \\
$\quad$ There is & 128 & 85.3 \\
$\quad$ There is no & & \\
Health works & 60 & 40 \\
$\quad$ Good & 90 & 60 \\
$\quad$ Less & 150 & 100 \\
Total & & \\
Source: Primary data, 2021 & &
\end{tabular}

\section{Bivariate test}

Based on the results of the bivariate analysis, it was found that the variables that had a relationship with the health service utilization variable were the knowledge variable with $p=0.001$. The knowledge variable shows that citizens who have less dominant knowledge categories do not take advantage of health services, namely, 76 families $(71.7 \%)$ and citizens who have good knowledge categories dominate using health services by 37 families (84.1\%). variable number

Table 4: Relationship between the characteristics of citizens with the utilizations of health services

\begin{tabular}{|c|c|c|c|c|c|c|}
\hline \multirow[t]{3}{*}{ Characteristics } & \multicolumn{4}{|c|}{ Utilization of health services } & \multicolumn{2}{|l|}{$\mathrm{p}$} \\
\hline & \multicolumn{2}{|c|}{ No } & \multicolumn{2}{|c|}{ Yes } & & \\
\hline & $\mathrm{n}$ & $\%$ & $\mathrm{n}$ & $\%$ & $\mathrm{n}$ & \\
\hline \multicolumn{7}{|l|}{ Knowledge } \\
\hline Good & 76 & 71.7 & 30 & 28.3 & 106 & 0.001 \\
\hline Less & 7 & 15.9 & 37 & 84.1 & 44 & \\
\hline \multicolumn{7}{|l|}{ Health Insurance } \\
\hline Have & 64 & 54.2 & 54 & 45.8 & 118 & 0.750 \\
\hline Don't Have & 19 & 59.4 & 13 & 40.6 & 32 & \\
\hline \multicolumn{7}{|c|}{ Number of families } \\
\hline Big & 33 & 70.2 & 14 & 29.8 & 47 & 0.021 \\
\hline Small & 50 & 48.5 & 53 & 51.5 & 13 & \\
\hline \multicolumn{7}{|l|}{ Transportation } \\
\hline Difficult & 12 & 44.4 & 15 & 55.6 & 27 & 0.297 \\
\hline Easy & 71 & 57.7 & 52 & 42.3 & 27 & \\
\hline \multicolumn{7}{|c|}{ Perception of pain } \\
\hline Less & 57 & 71.2 & 23 & 28.8 & 80 & 0.001 \\
\hline Good & 26 & 37.1 & 44 & 62.9 & 70 & \\
\hline \multicolumn{7}{|l|}{ Family support } \\
\hline Less & 61 & 62.2 & 37 & 37.8 & 98 & 0.030 \\
\hline Good & 22 & 42.3 & 30 & 57.7 & 52 & \\
\hline \multicolumn{7}{|c|}{ Reference group support } \\
\hline Less & 56 & 62.2 & 34 & 37.8 & 90 & 0.056 \\
\hline Good & 27 & 45 & 33 & 55 & 60 & \\
\hline
\end{tabular}

of families with $p=0.021$. In the variable number of families, it shows that citizens who are included in the category of small families dominantly utilize health services by 53 families (51.5\%) and citizens who are included in the dominant large family category do not utilize health services by 33 families $(71.2 \%)$.

In the family support variable with $p=0.030$. On the family support variable, it shows that citizens in the less dominant family support category did not take advantage of health services by 61 families (62.2\%) and citizens in the good family support category were dominant in using health services by 30 families $(57.7 \%)$. Then, the pain perception variable with $p=0.0001$. The pain perception variable shows that citizens who are included in the perception of pain category are less dominant who do not use health services by 57 families $(71.2 \%)$ and citizens who are included in the category of good perception of illness are dominant using health services by 44 families $(62.9 \%)$. The variables that have no relationship with the dependent variable are insurance ownership, transportation, reference group support, distance, health information, and health workers (Table 4).

The results of the bivariate analysis on the health worker variable with the health service utilization variable explained that the citizens who considered the attitude of health workers to be less dominant did not take advantage of health services by 50 families (55.6\%) and citizens who had different attitudes of health workers were dominant not using health services by 33 KK (55\%). The result of statistical test resulted in $p=1.000$ which stated that the variable of health workers' attitudes with the variables of health service utilization did not have a significant relationship (Table 5).

Table 5: Relationship between the characteristics of health care with the utilizations of health services

\begin{tabular}{|c|c|c|c|c|c|c|}
\hline \multirow[t]{3}{*}{ Characteristics } & \multicolumn{4}{|c|}{ Utilization of health services } & \multicolumn{2}{|c|}{$p$ value } \\
\hline & \multicolumn{2}{|c|}{ No } & \multicolumn{2}{|c|}{ Yes } & & \\
\hline & $\mathrm{n}$ & $\%$ & $\mathrm{n}$ & $\%$ & $\mathrm{n}$ & \\
\hline \multicolumn{7}{|l|}{ Distance } \\
\hline Far & 18 & 47.4 & 20 & 52.6 & 38 & 0.340 \\
\hline Close & 65 & 58.0 & 47 & 42.0 & 112 & \\
\hline \multicolumn{7}{|c|}{ Health Information } \\
\hline There is no & 69 & 53.9 & 59 & 46.1 & 128 & 0.538 \\
\hline There is & 14 & 63.6 & 8 & 36.4 & 22 & \\
\hline \multicolumn{7}{|l|}{ Health works } \\
\hline Less & 50 & 55.6 & 40 & 44.4 & 90 & 1.000 \\
\hline Good & 33 & 55 & 27 & 45 & 60 & \\
\hline
\end{tabular}

\section{Multivariate test}

Based on the results of the multivariate analysis, it shows that the knowledge variable, family support variable, the number of family variable, and the sickness perception variable have a significant

Table 6: The dominant variable related with the health service utilization

\begin{tabular}{llll}
\hline Variable & Coef B & $\mathrm{p}$ & OR \\
\hline Knowledge & 2.555 & 0.001 & 12.876 \\
Family Support & 1.031 & 0.019 & 2.803 \\
Number of Families & 1.072 & 0.028 & 2.920 \\
Perception of Pain & 1.057 & 0.001 & 2.877 \\
Constant & -2.552 & & \\
\hline Source: Primary data, 2021 & & &
\end{tabular}


relationship with the utilization of health services. The dominant variable can be seen from the size of the odds ratio (OR). The greater the OR obtained, the more dominant the variable is. In this study, the knowledge variable was obtained with OR 12.876 which is the largest OR. The dominant variable in the utilization of health services is the knowledge variable (Table 6).

\section{Discussion}

\section{Knowledge}

According to the theory put forward by Green (1980), the behavior of health service utilization is caused by three factors, one of which is predisposition. The predisposing factor consists of several factors, one of which is the knowledge factor. This theory explains that the utilization of health services is related to public knowledge regarding health services. The higher the knowledge, the community will take advantage of health services [6].

The findings in this study state that there is a relationship between the knowledge variable and the dependent variable. In the research findings, the chi square test shows the $p$ value of the knowledge variable, namely, 0.001 , which means that there is a relationship between the knowledge variable and the dependent variable. These results describe citizens who have less knowledge will not take advantage of health services and citizens who have good knowledge of health services will use more health services [6].

The findings of this study are in line with other studies which state that knowledge is related to the use of health services. $p$ value in the variable knowledge $p=0.001$ [7]. The results of the statistical test in this study are also in line with Raharjo's research in 2017 which states that the $p=0.000$ which shows that the knowledge variable with the health service utilization variable has a significant relationship [8].

\section{Insurance}

According to Adersen's (1975) theory, there is a relationship between ownership of health insurance and the use of health services. This is in the enabling factor. The health insurance factor is an important factor in the utilization of health services. People can better anticipate times of illness by having health insurance. If the community is sick with health insurance, they can be exempted from treatment [5].

Based on the analysis, the variable of health insurance ownership with the dependent variable got a $p=0.750$ which indicates that the variable of health insurance ownership with the dependent variable has a significant relationship. The results explain that those who do not have health insurance do not take advantage of health services and those who have health insurance also do not dominate the use of health services. Hence, there is no relationship between having and not having health insurance.

However, this study is not in line with the research which states that the variable of health insurance ownership has a relationship with the variable of health service utilization. The research got the $p=0.001$ which shows that the variable of health insurance ownership and the variable of health service utilization has a significant relationship [5].

The difference in the results of research regarding the ownership of health insurance against the utilization of health services is caused by differences in research locations. In this study, the factors that made the ownership of health insurance were not related, namely at least 32 citizens families out of 150 citizens households and 107 poor knowledge and poor perceptions of illness as many as 80 families.

\section{Number of families}

Economic income or expense affects the utilization of health services [9]. According to the theory of Andresen and Andreson (1979), it is revealed that the number of families is a demographic factor that can lead to increased utilization of health services by the community.

The results of the findings in this study can be assumed that the more family members there are, the less health services are used. Based on the results of research on the chi square test, it was found that the value of $p=0.021$, which indicates that the variable number of families with the dependent variable has a significant relationship.

The results of this study are in line with the research disclosed by Laili in 2008 which explained that the variable number of families and the variable utilization of health services had a significant relationship with $p=0.002$ [10]. There is an influence on the variable number of family members with the use of health services because there is a relationship with expenditure caused by the large number of families so that families tend to prioritize food needs more than seeking treatment to health services for family members who suffer from illness, especially mild illness. This results in the low utilization of health services by citizens.

\section{Perception of pain}

The utilization of health services in health services such as Puskesmas, clinics, hospitals and other health service facilities is quite low. The low utilization of health services by the community is due to the perception and concept of illness that is owned by the community. Perception of pain is an experience that is captured 
through the five senses. Each person's perception varies depending on one's motivation to do something. If the perception seseorang is correct against the person's pain, then tend to use health services [11]. According to the theory of Green (1980), there is a relationship between the perception of pain and the utilization of health services. This is in the driving or disposing factors. Utilization of health services will be related to perceptions that exist in oneself and in society regarding health.

The results of the study can be concluded that the more a person has a good perception, the more likely that person is to take advantage of health services. The results of the analysis on the chi square test obtained $p=0.001$ which indicates that the pain perception variable with the dependent variable has a significant relationship.

Based on these results, this study is in line with Primanita's research in 2011 which states that the variable perception of pain and the variable of health service utilization has a significant relationship but has a weak correlation [12]. In the same study, research conducted by Raharjo in 2017 obtained $p=0.001$ which means that the perception of pain variable with the variable of health service utilization has a significant relationship.

Fatimah and Indrawati's research in 2019 stated that the variable perception of pain was related to the variable of health service utilization with a value of $p=0.001$. Pain can be felt by everyone. However, the pain that a person experiences in his judgment is different. Respondents in this study said they were sick, if they could not carry out their daily activities and would only go to health services [13].

\section{Family support}

The family is a physical and social supporter in finding and using the right health services [14]. Family support can vary according to the circumstances of family life. Family support aims to provide motivation with positive inputs to seek treatment.

Based on the results of the study, the value of $p=0.030$ shows that the variable family support with the health service utilization variable has a significant relationship. Hence, the findings in this study can be assumed that the better family support for health services, the greater the utilization of health services. The less family support, the lower the utilization of health services. The family supports it by suggesting going to a health service when sick and by volunteering to deliver to health services.

The findings in this study are the same as those stated by Anggraini in 2019 which states that the family support variable is related to the health service utilization variable with a value of $p=0.000$ [7]. Another study which states that the family support variable has a relationship with the health service utilization variable, namely, the research conducted by Sampoerna et al., in 2013 obtained $p=0.001$ [15]. The same is the case with research conducted by Reda et al. in 2018 [16].

\section{Reference group support}

Reference groups are groups that are useful for providing references to other people to decide on purchases and consumption [17]. According to the theory of Lawrence Green (1980), it is revealed that the support of community leaders, family and friends is related to the use of health services. Reference group support is on the reinforcing factor.

Based on the research results obtained $p=0.056$, which means that the reference group support variable with the health service utilization variable does not have a significant relationship. The results of this study reveal that the better the support from the reference group, the greater the utilization of health services. On the other hand, the less support from the reference group, the lower the utilization of health services, but in this study there was a fairly close difference between support from a good reference group and a lack of reference group. This makes the decision that there is no relationship between reference group support and the use of health services.

The expression of the results of the study is not in line with the research conducted by Sampeluna in 2013 which stated that the reference group support variable with the health service utilization variable had a significant relationship because the $p=0.001$ [15]. Reference group support plays an important role in providing information related to the existence of health service facilities and the quality of health services. Providing information affects perceptions in society. These perceptions influence the behavior of health service utilization [18]. However, social support or support made by relatives or friends is sometimes unwilling to provide support, understanding and affection for those in need [19]. This is in line with the result that there is more family support compared to reference group support which influences community decisions in utilizing health services because the community's decision in utilizing health services lies within a family.

\section{Distance}

The low utilization of health services is caused by the distance between health services from where residents live. People are more likely to take advantage of health services in the neighborhood where they live [20]. According to the theory of Andresen and Andreson (1979), there is a relationship between the distance variable and the health service utilization variable. Distance goes into the community resource factor. The closer the health service is to the community residence, the more people will use health services. 
Based on the results of the study, it was found that more citizens went to services that were close to those who were far away. However, in the past 1 year, citizens who are close to each other do not take advantage of health services and citizens who are far away are quite balanced in utilizing health services. From the results of the chi square analysis, it was found that the $p=0.340$, which means that the distance variable does not have a significant relationship with the dependent variable.

The findings in this study are in line with the research conducted by Yustina and Balqis in 2015 which stated that the distance variable and the health service utilization variable did not have a significant relationship because the results obtained $p=0.804$ [5]. Research conducted by (Panggantih, 2019) also obtained $p=0.606$, which means that the distance variable with the health service utilization variable does not have a significant relationship [21].

The findings in this study can be assumed that citizens who are near or far away do not affect the utilization of health services. The citizens said that it had no effect on health care being near or far away because when they were compatible with the health service facility, they would continue to go to the health service facility they chose even though the health service location was quite far away. Then one of the factors that prevent citizens from going to health service facilities even though they are close is because the illness they suffer can still be treated by themselves or are mildly ill.

This assumption is in line with the Donabedian theory (1973) in Dever (1984) which states that geographic distance or access is related to the use of health services but it can also be unrelated due to other factors that can be related to geographic distance or access, namely minor complaints or mild illness felt by the community.

\section{Transportation}

According to the theory of Thandues and Maine (1990), the factors that cause behavior that can benefit health services are quality of health services, patient characteristics, ease of service. The availability of health services is included in the facilities and infrastructure. Then, the convenience of health services includes costs, transportation, and health information.

The results of the study showed $p=0.297$ which stated that the transportation variable and the health service utilization variable did not have a significant relationship. This study assumes that there is an unidirectional relationship between the transportation variable and the utilization of health services because in this study the results of easy transportation are more than difficult transportation. Hence, the citizens who have easy or difficult transportation have nothing to do with the use of health services based on observations Citizens are more likely to own a motorized vehicle and walk to the health service. So that there are no obstacles even though public transportation advice is inadequate.

Other studies also state the same thing that the transportation variable with the variable utilization of health services does not have a significant relationship [22]. However, the results of the findings in this study are not in line with Raharj's 2017 research which states that the transportation variable and the health service utilization variable have a significant relationship [8]. This was also revealed by Fatimah and Indrawati in 2019 that the transportation variable with the health service utilization variable had a significant relationship because it was obtained $p=0.001$ [13].

\section{Health information}

The existence of health promotion and information is very effective in seeing whether or not health service facilities are good. According to the theory of Thandues and Maine (1990), the factors that cause behavior that can benefit health services are quality of health services, patient characteristics, ease of service. The convenience of health services includes costs, transportation, and health information. Health information in this study was in the form of health counseling conducted by the Tangerang Selatan, Indonesia Health Center for the past year.

The results showed that health counseling in the citizens settlements in Tangerang Selatan, Indonesia tended not to exist only in one area. Then the research results obtained on the Chi-square test, namely, the health information variable with the health service utilization variable which has a $p=0.538$. These results can be assumed that if there is no health information then the use of health services has no effect. This happens because of a situation that requires citizens to go to health services. These findings are in line with Engel (1995) who stated that decisions in the use of health services are a combination of normative needs and perceived needs to make use of health services.

In Anggraini's research in 2019 said the health information variable with the use of health services had a significant relationship because the $p$ value was obtained $=0.001$ [7]. Research conducted by Raharjo in 2017 shows that information can be related to the use of health services [8]. The same is the case with research by Reda et al. The year 2018 states that there is an influence between information and the use of health services [8].

\section{Health workers}

The attitude of health workers can be interpreted as a response or reaction given by the nurse/doctor in serving patients as needed. In fact, at present many 
health services do not care about patient complaints and do not care about patient rights. Thus, the attitude of health workers with the use of health services has an effect [11]. According to Andersen's (1975) theory, there is a relationship between health workers and the use of health services on the characteristics of the capability of community resources. In the theory of Andresen and Andreson (1979), it is also revealed that there is a relationship between health workers and the utilization of health services on organizational factors.

Based on the research results, it shows that the value of $p=1.000$, which means that the attitude variable of health workers with the dependent variable does not have a significant relationship. The results of this study are in line with research conducted by Wulandar et al. In 2019, the results showed that the value of $p=0.288$, which means that the variable of health workers and the variables of health service utilization did not have a significant relationship [22]. However, the results of this study do not have the same results with Irianti's 2018 research which states that the attitude variable of health workers has a relationship with the variable utilization of health services with a value of $p=0.037$ [11].

\section{Multiple logistic regression analysis}

Based on the results of research using the multivariate test, it shows that the knowledge variable $(p=0.001)$, the family support variable $(p=0.019)$, the number of families variable (0.028), and the pain perception variable $(p=0.001)$ have a significant relationship with the use of health services. The dominant variable can be seen from the size of the OR. The greater the OR obtained, the more dominant the variable is. In this study, the knowledge variable was obtained with an OR of 12.876 which was the largest OR. The dominant variable in the utilization of health services is the knowledge variable.

These results are in line with the theory of Lawrence Green (1980) which states that knowledge has a relationship with the utilization of health services. Knowledge is very important for the survival of society, especially in terms of health. Knowledge can change the mindset and behavior of a person or community group in response to something. The better the knowledge of a person or group will broaden horizons that will lead to the use of health services. The knowledge factor also greatly influences the habits of a person or community group [23].

\section{Conclusion}

Citizens at the Tangerang Selatan Area who did not take advantage of health services during the past year were 83 households $(55.3 \%)$ and those who utilized health services were 67 families (44.7\%).
The results showed that the variables of knowledge ( $p=0.001)$, number of families $(p=0.021)$, perception of pain ( $p=0.001)$, and family support $(p=0.030)$ had a relationship with the use of health services by citizens at Area, Tangerang Selatan, Indonesia. The results showed that the knowledge variable was the dominant variable in the utilization of health services by citizens in the area of Tangerang Selatan, Indonesia with an OR result of 12.876 .

\section{Suggestion}

Suggestions from researchers are expected that health services contain more programs that are directly related to the community around the Area, suggestions from health service researchers can make health information provision programs and information on the importance of using health services. The lower the public's knowledge of health information, the less health information is conveyed by health workers.

\section{Thank-you Note}

Thank you to the Faculty of Health Sciences, Universitas Pembangunan Nasional Veteran Jakarta, Setu District, as well as the lecturers of the UPN Veteran Jakarta and friends who have helped and supported this research.

\section{References}

1. Kemenkes R. Membangun Manusia Indonesia Menuju Negara Maju dan Sehat. Available from: https://www.kemkes.go.id/ article/print/1810260 0003/membangun-manusia-indonesiamenuju- negara-maju-dan-sehat.html [Last accessed on 2020 Oct 11]

2. Kemenkes RI. Profil Kesehatan Indonesia. Kemenkes RI; 2019

3. Sianturi E, Pardosi M, Surbakti E. Kesehatan Masyarakat. Sidoarjo: Zifatama Jawara; 2019.

4. Pynkyawati T, Wahadamaputera S. Utilitas Banguan Modul Plumbing. Jakarta: Griya Kreasi; 2014

5. Yustina L, Balqis D. Factor Relate to Usage With Health Service of Trash Picker in Tamangapa Landfill. Kesehat Masy Univ Hasanuddin; 2015. p. 6-7. Available from: http:// repository.unhas.ac.id/bitstream/handle/123456789/14461/ YUSTINALOGENK1111408.pdf?sequence=1 [Last accessed on 2021 Jul 23].

6. Aisyah Zalmar N. Pemulung Di Tpa Tamangapa Antang Tahun 2016. Skripsi; 2016.

7. Anggraini I. Factors influencing the utilization of health services of the poor in RSUD Nias District 2019. J Health Reprod. 
2019;4(2):22-36.

8. Raharjo AP. Pemanfaatan pusat layanan kesehatan (Puslakes) Universitas Negeri Semarang. Higeia. 2017;1(4):49-60.

9. Riyanti FF, Fadhila DA, Fauziah NA, Amirudin A, Suripto Y, Wattimena $\mathrm{L}$. Hubungan antara tingkat pendapatan dengan pemanfaatan pelayanan kesehatan oleh pasien jaminan kesehatan nasional. J IIm Kesehat. 2019;18(3):98-101. http:// doi.org/10.33221/jikes.v18i3.369

10. Laili LE. Pengaruh Karakteristik Masyarakat Miskin Dan Pelayanan Kesehatan Terhadap Pemanfaatan Pelayanan Rumah Sakit Umum Daerah Pandan Kabupaten Tapanuli Tengah Tahun 2007, 2008 USU Repository (C) 2008. Skripsi; 2008.

11. Irianti I. Faktor yang berhubungan dengan Pemanfaatan Pelayanan Kesehatan Petani Rumput Laut Desa Garassing Kecamatan Bangkala Barat Kabupaten Jeneponton Tahun 2018. Skripsi; 2018. p. 1-120

12. Primanita A. Hubungan Antara Persepsi Tentang Sakit Dengan Pemanfaatan Pelayanan Kesehatan Oleh Peserta Jaminan Kesehatan Masyarakat Di Puskesmas Gunungpati Kota Semarang. Skripsi; 2011. p. 9-21. Available from: http://lib. unnes.ac.id/5819/1/7564.pdf. [Last accessed on 2021 Jan 04].

13. Fatimah $S$, Indrawati F. Utilization of Health Care. Higeia $J$ Public Heal Res Dev. 2019;3(1):121-31.

14. Sahar J, Setiawan A, Riasmini. Keperwatan Kesehatan Komunitas Dan Keluarga. Singapore: Elsevier Ltd.; 2019.

15. Sampeluna N, Balqis, Hamzah A. Determinant of health care utilizations in RSUD Lakipadada Kabupaten Tana Toraja. J AKK. 2013;2(3):1-7.
16. Reda SM, Krois J, Reda SF, Thomson WM, Schwendicke F. The impact of demographic, health-related and social factors on dental services utilization: Systematic review and meta-analysis. J Dent. 2018;75(February):1-6. doi:10.1016/j.jdent.2018.04.010

17. Kotler P. Manajemen Pemasaran: Analisis, Perencanaan, Implementasi Dan Pengendalian Jilid 1. Jakarta: Erlangga; 2013.

18. Usman AH. Fakultas Kesehatan Masyarakat Universitas Hasanuddin Makassar 2014. University Hasanuddin Fak Kedokt Gigi Makassar; 2014.

19. Marnah M, Husaini H, IImi B. Analisis perilaku masyarakat dalam pemanfaatan pelayanan kesehatan peserta program keluarga harapan (Pkh) di kecamatan paminggir. J Berk Kesehat. 2017;1(2):130. http://doi.org/10.20527/jbk.v1i2.3152

20. Sitorus H. Gambaran Aksesibilitas Sarana Pelayanan Kesehatan di Propinsi Kepulauan Bangka Belitung (Analisis Data Riskesdas 2007); 2017. p. 24-30. Available from: http:// ejournal.litbang.depkes.go.id/index.php/s pirakel/article/ view/6109/4697

21. Panggantih A. Faktor-Faktor Yang Berhubungan Dengan Pemanfaatan Pelayanan Kesehatan Oleh Peserta Jaminan Kesehatan Nasional (Jkn) Di Puskesmas Mekarsari Tahun 2019. Skripsi; 2019.

22. Wulandar C, Ahmad LO, Syawal KS. Hubungan Antara Pengetahuan, Sikap Dan Pendapatan Dengan Pemanfaatan Puskesmas Oleh Masyarakat Desa Kima Bajo Kecamatan Wori, Kesmas; 2019.

23. Muzakkir. Dukun Dan Bidan Dalam Perspektif Sosiologi. Makasar: CV SAH Media; 2018. 